Columbia Law School

Scholarship Archive

Faculty Scholarship

Faculty Publications

2020

\title{
Global Investor-Director Survey on Climate Risk Management
}

Kristin Bresnahan

Jens Frankenreiter

Sophie L'Helias

Brea Hinricks

Nina Hodzic

See next page for additional authors

Follow this and additional works at: https://scholarship.law.columbia.edu/faculty_scholarship

Part of the Business Organizations Law Commons, and the Environmental Law Commons

\section{Recommended Citation}

Kristin Bresnahan, Jens Frankenreiter, Sophie L'Helias, Brea Hinricks, Nina Hodzic, Julian Nyarko, Sneha Pandya \& Eric L. Talley, Global Investor-Director Survey on Climate Risk Management, CoLUMBIA LAW \& ECONOMICS WoRKING PAPER No. 650 (2020).

Available at: https://scholarship.law.columbia.edu/faculty_scholarship/2721

This Report is brought to you for free and open access by the Faculty Publications at Scholarship Archive. It has been accepted for inclusion in Faculty Scholarship by an authorized administrator of Scholarship Archive. For more information, please contact scholarshiparchive@law.columbia.edu. 


\section{Authors}

Kristin Bresnahan, Jens Frankenreiter, Sophie L'Helias, Brea Hinricks, Nina Hodzic, Julian Nyarko, Sneha Pandya, and Eric L. Talley 


\title{
Global Investor-Director Survey on Climate Risk Management
}

\author{
Kristin Bresnahan, Jens Frankenreiter, Sophie L’Hélias, Brea Hinricks, Nina Hodzic, Julian \\ Nyarko, Sneha Pandya, and Eric Talley ${ }^{1}$
}

\section{Introduction}

In recent years, a growing chorus of commentators and policy makers have begun to question anew the role and purpose of the corporation, with a level of scrutiny not seen in over a generation. Although the "shareholder primacy” model of corporate governance still holds considerable sway in both the board room and the court room, nearly all relevant actors are reevaluating the core commitments of that model. The calls for re-visioning have come not just from usual quarters (e.g., champions of regulation and advocates for employees and public interest causes), but also from traditional defenders of the shareholder-centric model, including important investor groups as well as major managerial representatives (such as the Business Roundtable). In short, the corporate governance tent is rapidly expanding to admit a larger and more heterogeneous audience.

That expansion is nowhere more profound than in matters concerning climate change. There is growing consensus that climate change is among the most pressing public crises of our time, and the role of corporate actors in this space looms large. And accordingly, the challenge of

\footnotetext{
${ }^{1}$ The authors are, respectively, General Counsel, Alpine Roads, Inc. (Bresnahan), Postdoctoral Fellow, Millstein Center at Columbia Law School (Frankenreiter), Founder and President, LeaderXXchange LLC (L’Hélias), Assistant Director, Millstein Center at Columbia Law School (Hinricks), Advisory Board Member, LeaderXXchange and Director ESG Integration and Solutions, Allianz Global Investors (Hodzic), Assistant Professor of Law, Stanford Law School (Nyarko), Third-Year Columbia Law Student (Pandya), and Isidor \& Seville Sulzbacher Professor and Faculty Co-Director, Millstein Center at Columbia Law School (Talley). The views expressed in this paper are those of the authors and do not necessarily reflect the views of Allianz Global Investors.
} 
making headway in whether, how, and when corporate actors should embrace climate-related objectives is now upon us.

But to accomplish this task effectively, we must be informed by evidence. Best guesses and armchair conjectures are inadequate for the scope and depth of the current challenge. It is in this spirit that we offer the report below, which summarizes results from a survey of sophisticated investors and board directors - the relevant decision makers in assessing questions around climate risk, its interaction with corporate actors, and the disclosure thereof. We hope that the results of this survey will inform both public and private policy makers in navigating the current debate. It is far from the only type of evidence-based study that is needed, but no doubt an important start.

\section{About the Survey}

As noted in the introduction, changes in the global climate are having profound impacts on business operations, governance, and organizational management around the world. Boards of directors are searching for ways to account for these changes as they help guide their organizations, and investors are increasingly concerned about how these changes might impact their portfolios. According to some, climate change is “on the top of investors’ 2020 sustainability agendas for engaging with boards of the companies they invest in.”2 A key component of this competency, likely to be a significant question of corporate governance in the coming years, is climate risk management. Companies, investors, regulators, and other key market players must all be part of the conversation around how climate risks should be managed, disclosed, and incorporated into business strategy. And indeed, a growing number of investors

\footnotetext{
${ }^{2}$ Paulina Pielichata, Climate Change, Human Capital Top Investors' Agendas, Pensions \& Investments, Mar. 10, 2020, https://www.pionline.com/esg/climate-change-human-capital-top-investors-agendas.
} 
worldwide have committed to an engagement strategy requiring companies in their portfolios (virtually covering all public companies world-wide) to report under the Task Force on Climaterelated Financial Disclosures framework and disclose their sustainability performance according to standards articulated by the Sustainability Accounting Standards Board (SASB).

This global survey, conducted by a team of researchers at the Ira M. Millstein Center for Global Markets and Corporate Ownership at Columbia Law School and experts at LeaderXXchange ${ }^{\circledR}$, an organization that advises and promotes sustainability in governance, leadership, and investment, seeks to understand how—if at all—institutional investors and board directors incorporate climate-related issues in their investment decision making and their oversight responsibilities, respectively. It is the first global survey of its kind targeting both investors and directors to probe their responses on climate risk management using two tracks aggregated in a single survey.

The survey was built to reassess prior findings of the LeaderXXchange Investor-Director Dialogue on Climate-related Risk Management series ${ }^{3}$ and the LeaderXXchange InvestorDirector ESG Working Group. ${ }^{4}$ The group published its findings in January $2020 .^{5}$

One of the major research goals in conducting this survey was to understand and assess how environmental, social, and governance (ESG) issues, which feature heavily in academic research, influence investment and boardroom decisions in practice. ESG issues can range from climate change (our focus) to diversity in the workplace to executive compensation, and

\footnotetext{
${ }^{3}$ The LeaderXXchange Investor Director Dialogue on Climate-related Risk Management series was launched in 2016 together with Spencer Stuart's European Board Practice group.

${ }^{4}$ The LeaderXXchange Investor-Director ESG Working Group was formed in 2017. Comprised of six directors and six investors participating in their personal capacity, the group surveyed and reviewed best practices and created a roadmap to help boards, investors and management rapidly adapt to climate change.

${ }^{5}$ The LeaderXXchange Investor-Director ESG Roadmap was released on January 21, 2020 and draws upon research, discussions, and surveys of LeaderXXchange Investor-Director ESG Working Group members conducted between 2017 and 2019.
} 
companies have varying ways in which they respond to each of these issues in the boardroom. ${ }^{6}$ This survey attempts to bridge the gap between business and academia by developing academic research based on practical actions taken by investors and directors as they shape their climate risk management and investment strategies.

The survey collected data on a broad range of topics, including demographic information of respondents and their views on:

- materiality of climate change issues;

- $\quad$ extent of training on climate change issues;

- $\quad$ disclosure of climate risks;

- climate risk management and board oversight; and

- $\quad$ engagement and proxy voting on climate-related issues.

The survey was conducted over a period of three months in Summer 2019, during which the Millstein Center and LeaderXXchange ${ }^{\circledR}$ each contacted relevant organizations within their networks to help disseminate the survey to directors and investors globally. Both organizations also invited individual investors and directors within their networks to anonymously complete the survey. Most respondents were based in Europe and North America.

This report provides a full analysis of the survey findings; you may also find a short executive summary here.

\section{Demographics of Survey Respondents}

Respondents to the survey were assembled using a variety of convenience samples, each corresponding to various channels. Participants were invited by survey managers via personal

${ }^{6}$ KPMG, ESG, Strategy, and the Long View: a Framework for Board Oversight (2017). 
contacts, organizational events, and directed social media postings. Survey responses were

collected throughout the Summer of 2019 through each of these different outreach channels, thus staggering responses and minimizing complications that are often due to "snowball" sampling (i.e., uncontrolled word-of-mouth dissemination). ${ }^{7}$ The majority of early responses were from investors, but the full set of respondents also includes corporate directors. Overall, there were more than 130 respondents: approximately 40\% directors and 60\% investors from Europe (including UK) and North America.

Figure 1: Respondent Demographics - Role

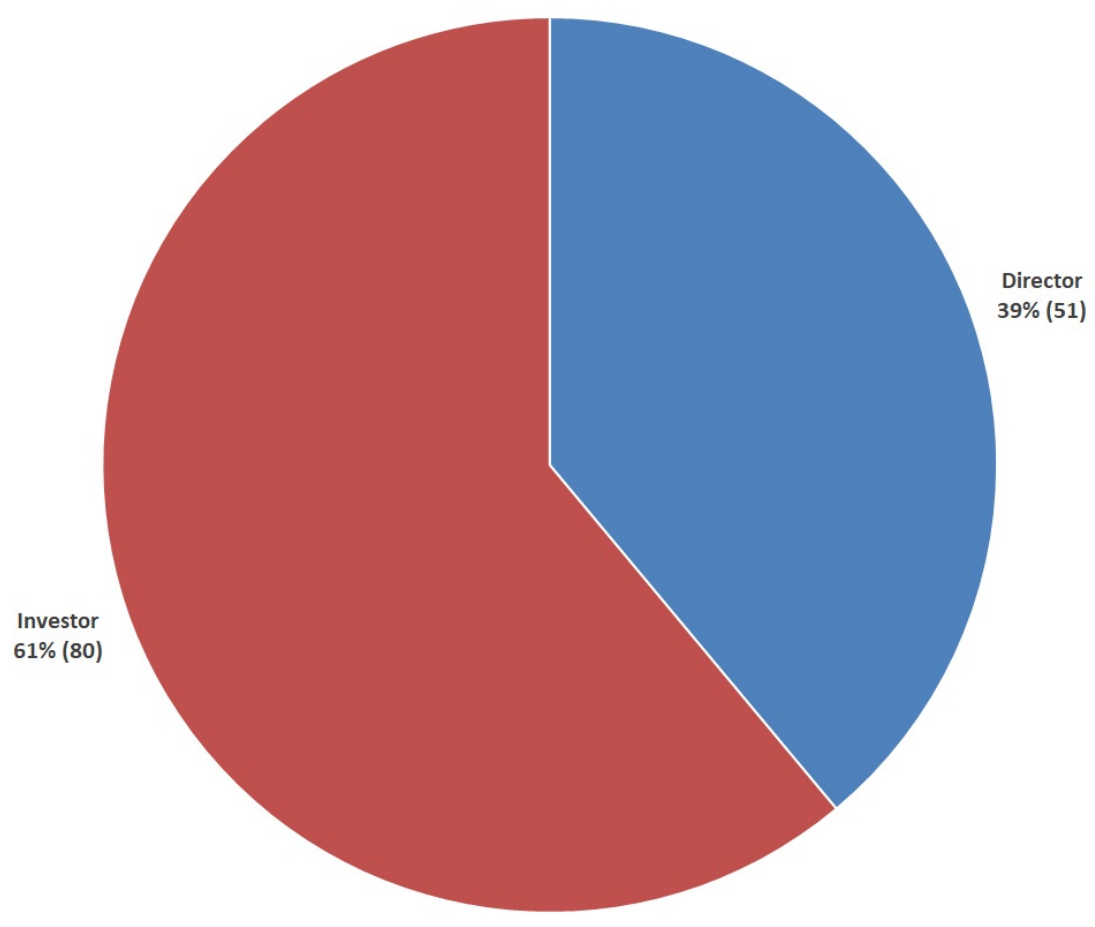

\footnotetext{
${ }^{7}$ Non-probabilistic sampling denotes any practice whereby participants in a study are not randomly selected from the population of potential participants, which gives rise to the possibility that responses obtained in a survey are not representative of the views of a broader population. Snowball sampling is one form of non-probabilistic sampling in which future participants in a study are recruited by asking previous participants for information on potential participants. The staggered responses we observed in this survey suggest that participants from various backgrounds participated in the study.
} 
A high level of disclosure by respondents provided excellent demographic insights: over $90 \%$ of respondents shared their age and gender. The survey responses also exhibited near gender parity with $53 \%$ female respondents, as well as a broad age distribution with $19 \%$ of respondents under 35 years of age, 34\% of respondents between $35-50$ years of age, 33\% of respondents between $50-65$ years of age, and $11 \%$ older than 65 years of age.

Figure 2 : Respondent Demographics - Gender and Age

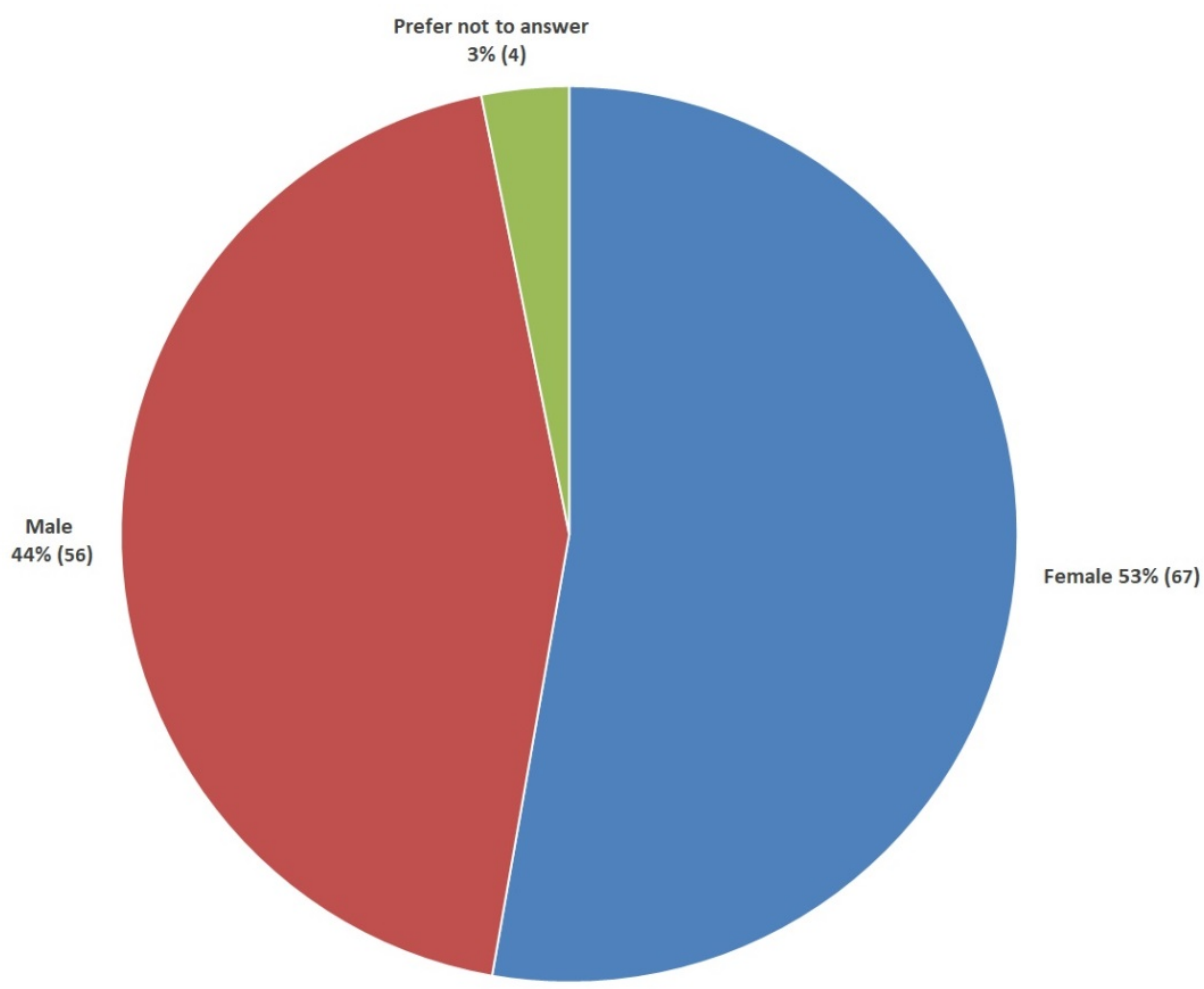

(a) Gender 


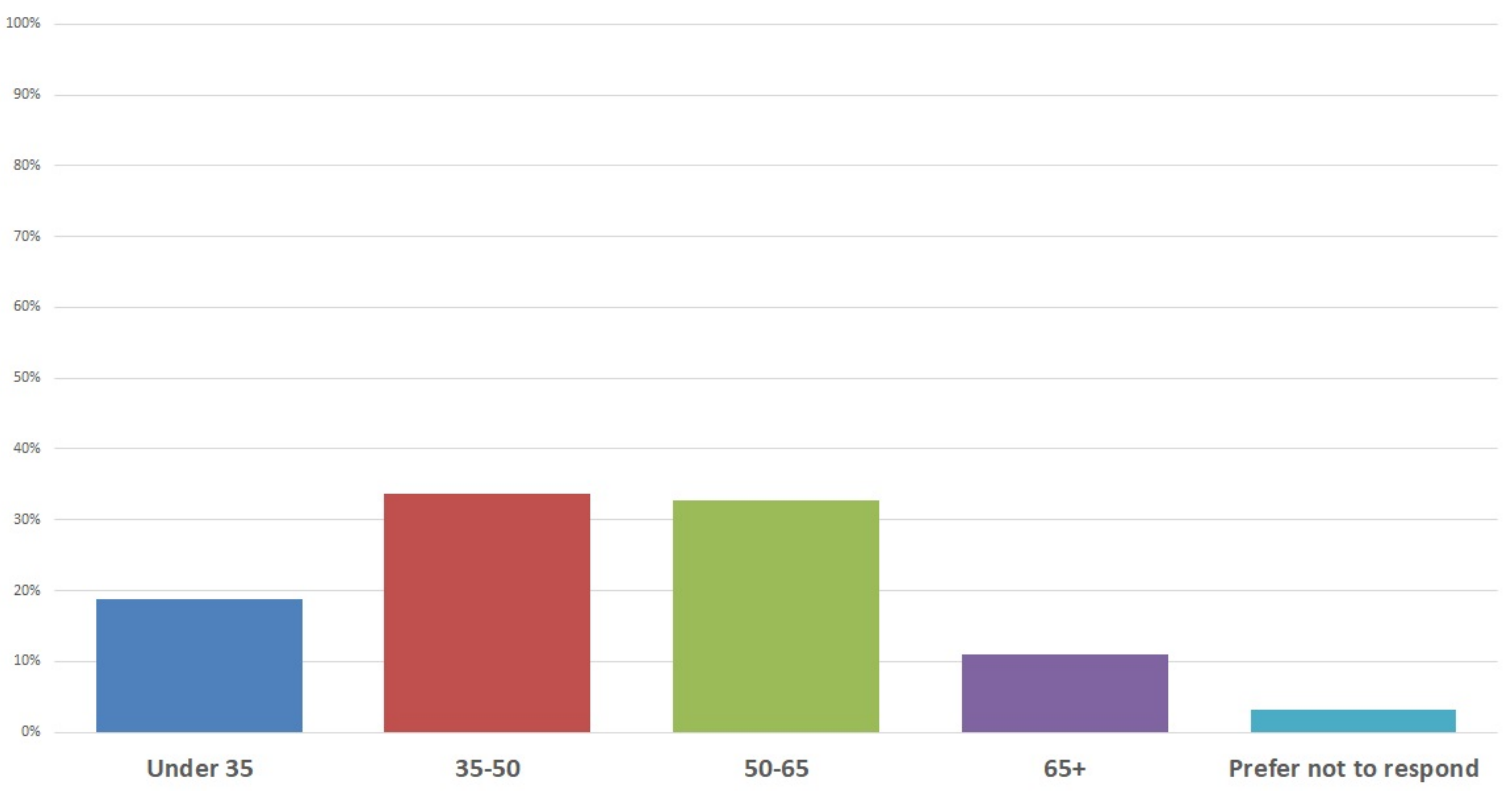

(b) Age

A diverse range of investor roles is represented among the survey respondents: from analysts, ESG specialists, and portfolio managers to Chief Investment Officers.

Figure 3: Role of Investor Respondents

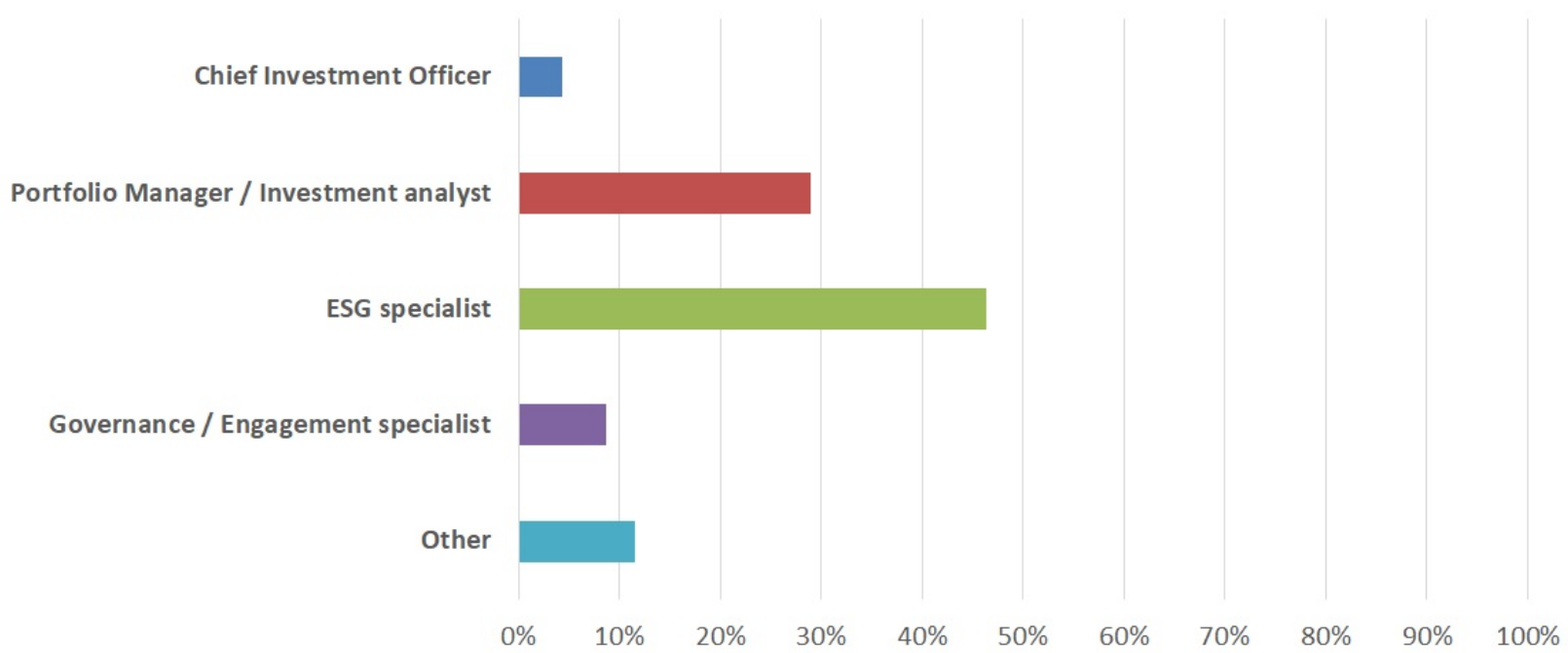

There is also a broad range of director roles and committees represented in the survey respondents: from Board Chairs and Lead Independent Directors, to members of the audit, risk, 
compensation, nominating, and/or governance, and corporate social responsibility (CSR)/sustainability committees.

Figure 4: Role of Director Respondents

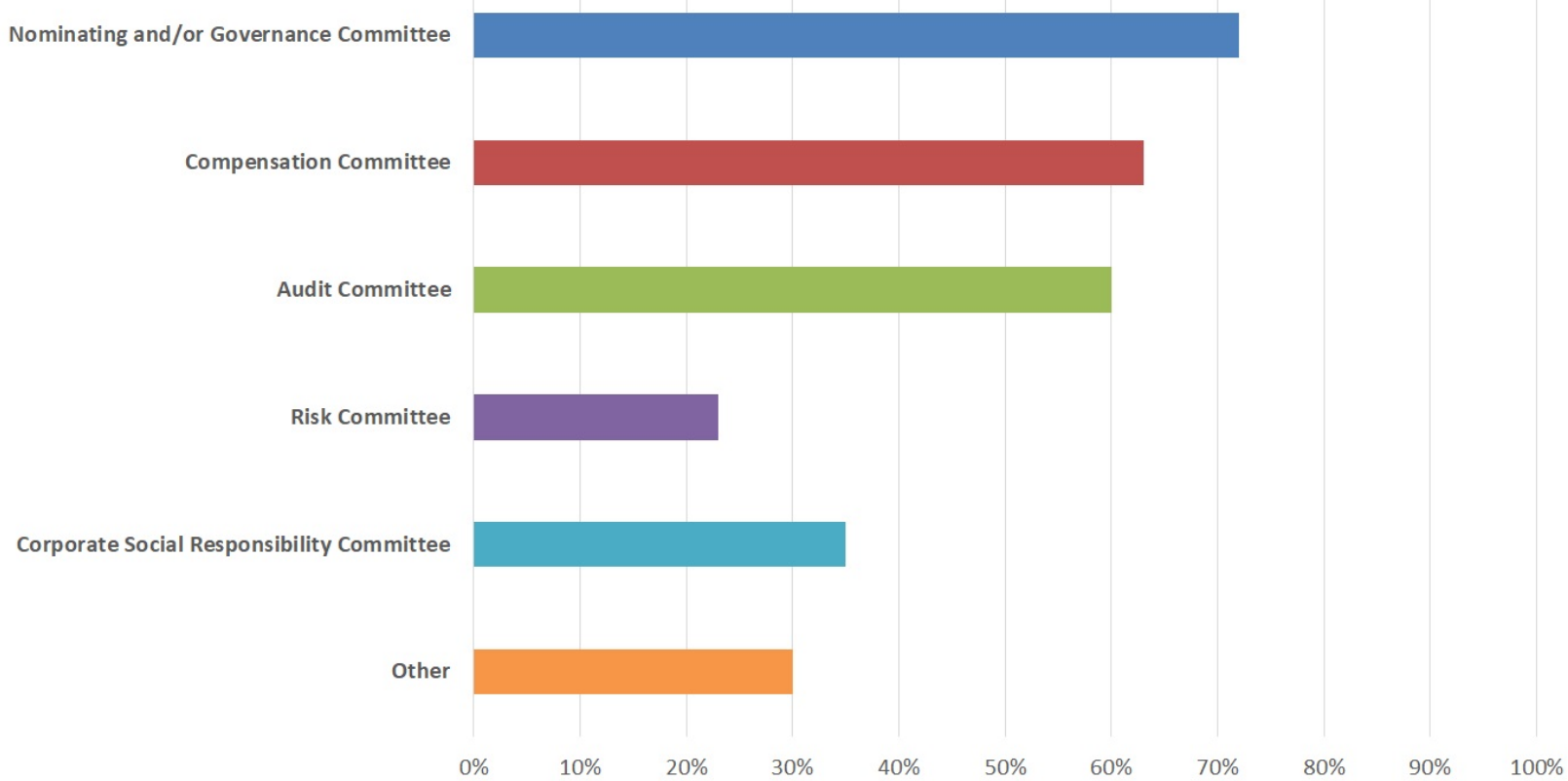

The range of participants in this global survey reflects in many ways the widespread challenge that climate risk management presents across all ages, genders, and roles in the business community throughout Europe and North America. The varied demographics of respondents provide a useful and dynamic metric to assess the strategic decisions of both board directors and investors in response to growing concerns around climate risks. Key findings from this survey thus represent a cross-section of the business community uniquely concerned with challenges posed by changes in the global climate. At the same time, our respondent population excluded C-suite members concerned with daily operations, mid-level business managers in geographic locations likely affected by climate change, and strategic advisors to the boards. Future research might expand the survey to include company management. 


\section{Key Findings}

Views of Investors and Directors on the Materiality of Climate Change Issues

In virtually all information disclosure regimes, a minimal threshold of "materiality" is imposed on what types of disclosures are necessary. In short, disclosures that are trivial or unimportant (i.e., "non-material”) generally need not be disclosed. That said, the precise definition of materiality has a notably self-referential character. Perhaps the most prominent definition—used in U.S. securities law—conceives of a fact as material if there is a substantial likelihood that a reasonable shareholder would consider it important in deciding how to vote their shares or make investment decisions. ${ }^{8}$ The following graph attempts to get a handle on the extent to which climate risk is perceived as material by survey respondents.

Figure 5: Perception of Climate Risk

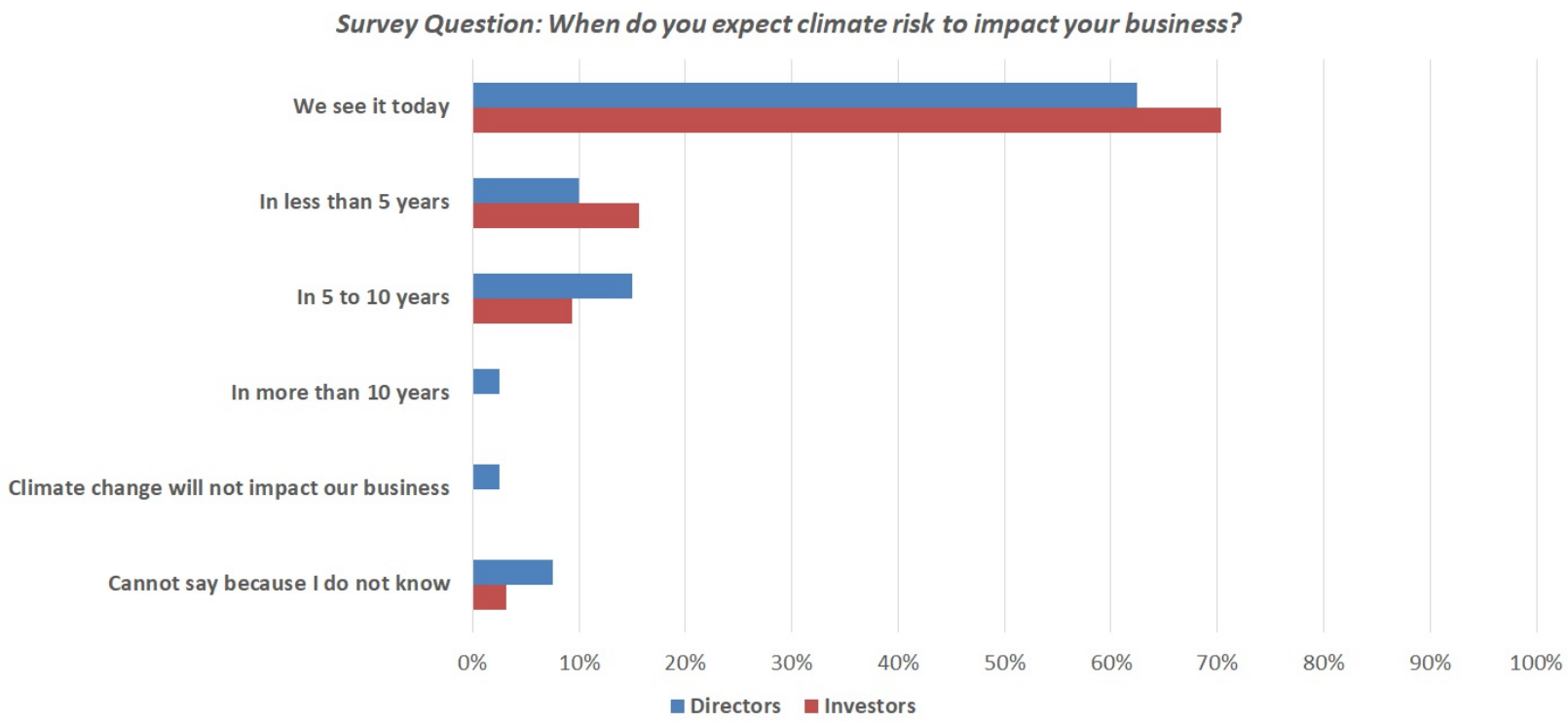

When investors and directors were asked when they expect climate risk to affect their business (with possible answers ranging from immediately (today) to further in the future (in

\footnotetext{
${ }^{8}$ TSC Industries, Inc. v. Northway, Inc., 426 U.S. 438 (1976).
} 
more than 10 years) or that climate change will not affect their businesses at all), responses suggest that both investors and directors believe climate change issues are material. More than $60 \%$ of directors and $70 \%$ of investors indicated that climate risk is already impacting their business today.

To understand the driving factors for investors and directors when incorporating climate risk into their strategy, respondents were given a range of potential motivations and concerns from which to select (e.g., that they are required to consider climate risk in response to regulatory obligations, that climate risk is important to shareholders, etc.). Ultimately, the main reasons for incorporating climate risk into strategy and investment decision making according to survey respondents were that doing so (i) helps identify business and investment opportunities, (ii) helps manage risk, and (iii) is the right thing to do.

For both strategy and investment analysis purposes, directors and investors see value in taking climate risk into account. Importantly, 75\% of respondents believe they hold an ethical obligation to incorporate climate risk into their strategy. Over $60 \%$ of investor respondents strongly agreed that incorporating climate risk into investment analysis and decision making helps manage investment risks, suggesting that it is indeed a material consideration for investors and directors alike. Not only does their perceived ethical obligation serve as an internal motivator to consider climate risk, investors and directors also identified additional, external incentives driving their behavior, including reputational concerns, outward-facing client preferences, and fiduciary duties.

The vast majority of respondents see some purpose in incorporating climate risk into their decisions. $80 \%$ of respondents disagreed with the proposition that any incorporation of climate risk in strategy is unimportant, thus emphasizing the material nature of climate change issues in 
strategy. Additionally, $90 \%$ of respondents disagreed with the idea that it is unimportant to incorporate climate risk into both investment analysis and decision making. Investors and directors are considering climate risk with marked certainty that it will figure into their strategy decisions in the present.

Figure 6: Views of Investors and Directors on the Role of Climate Change Issues Survey Question to Directors: Incorporating climate risk in our strategy...

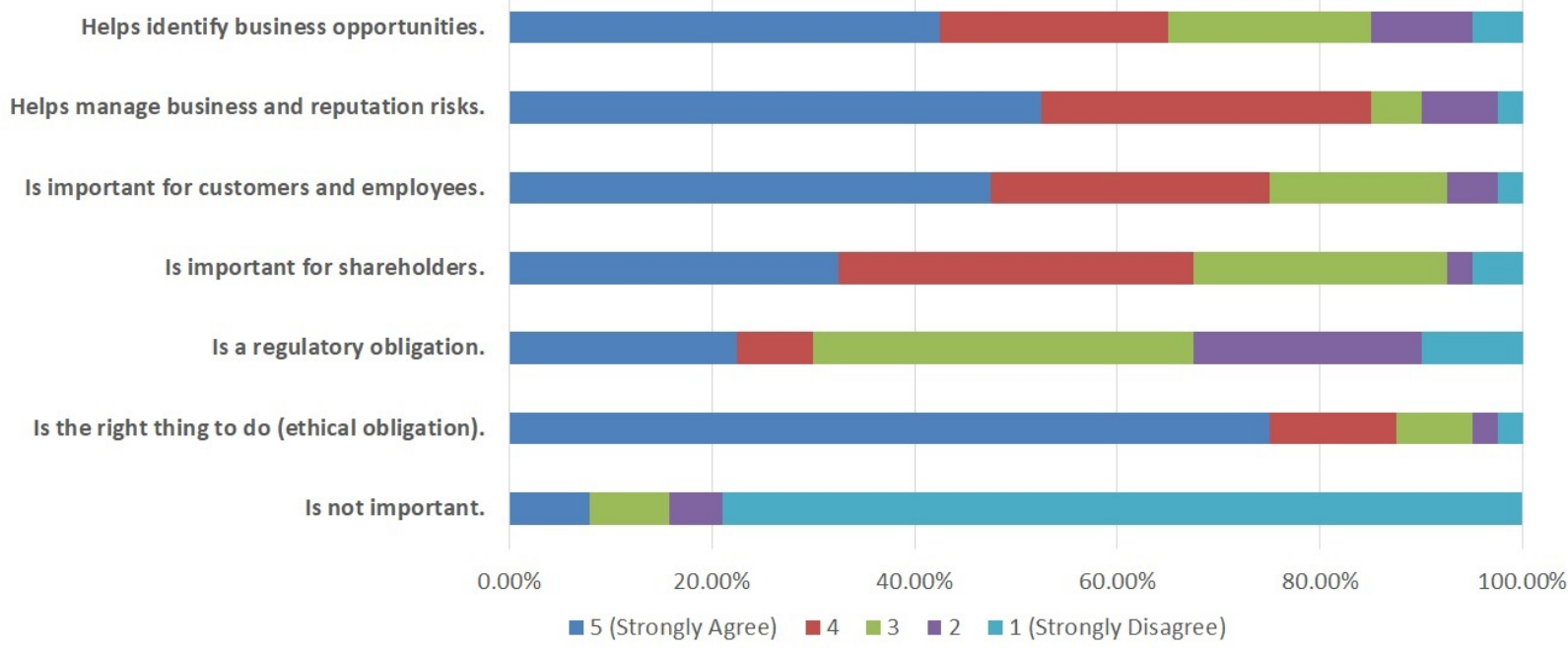

(a) Directors

Survey Question to Investors: Incorporating climate risk into investment analysis and decision making..

Helps identify investment opportunities in companies.

Helps manage investment risks.

Is important, as climate change performance is a proxy for management quality.

Is important for our clients. They are asking for it.

Is a regulatory obligation/fiduciary duty.

Is the right thing to do (ethical obligation).

Is good for our reputation.

Is not important.

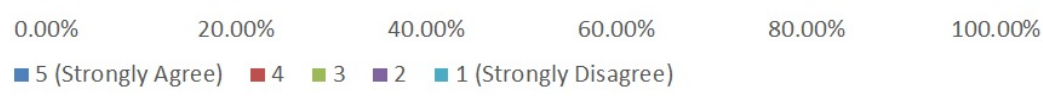

(b) Investors 
Views of Investors and Directors on Training on Climate Change Issues

A key component in measuring the responsiveness of investors and directors to climate change is the way they develop their own expertise and knowledge on the subject, which allows them to then assess a company's risk and opportunity profile. Both investors and directors developed their current understanding of climate change from a variety of sources. A majority of both investors and directors developed expertise on climate change by following current events and news reports in the media, reviewing publications by scientists and think tanks, and reading company CSR or annual reports. Investors, more so than directors, also turned to sell-side analyst reports and reports from ESG rating agencies as their preferred source of information. The majority of these information flows primarily utilized by investors and directors on climate risk are either publicly accessible or readily compiled within their companies, which may explain their prevalence in the training and development process. Less than $5 \%$ of investors, and $0 \%$ of directors, reported that they did not develop any knowledge or expertise in the area, demonstrating both that they believe climate risk issues are important and that training resources are widely available.

The results also show that investors and directors obtain their knowledge and expertise through both internal and external sources. Not surprisingly, investors were more heterogeneous than directors in the variety of means through which they receive information about climate change; such sources included internal trainings organized by their investment firms and external trainings. Relying on a single channel for information is not always a problem, but it can become one if that source itself is incomplete or curated for a targeted purpose. 
Figure 7: Sources of Information

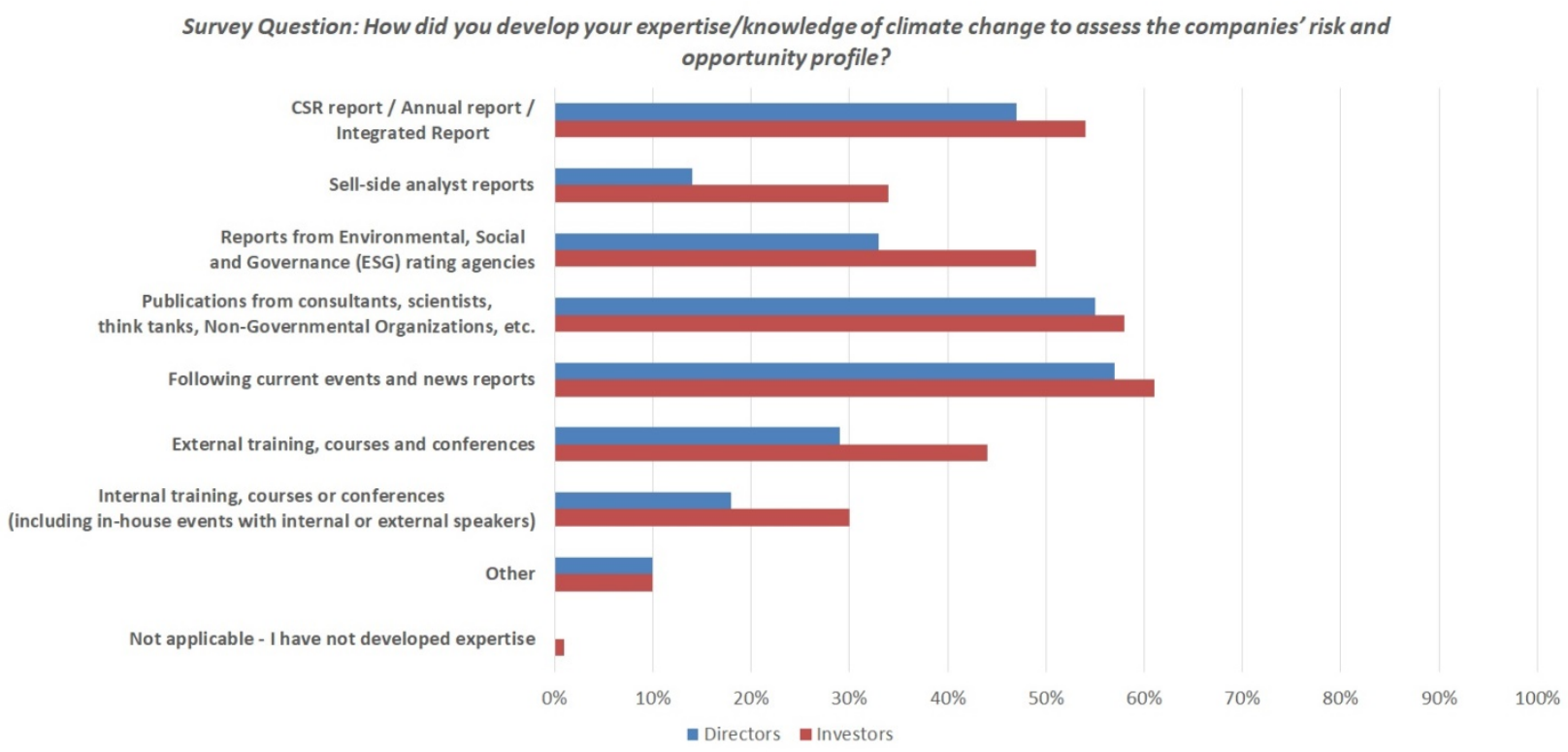

Views of Investors and Directors on Climate Disclosure

Disclosure of climate risk could prove to be a significant deciding factor for investors and directors in their strategic management as the effects of climate change intensify. Climate disclosures are part of a growing practice, which began with disclosure of carbon emission, for investors to become aware of efforts companies take to combat climate change, according to “Best Practices in Corporate Climate Disclosure” authored by S\&P Global. ${ }^{9}$ When investors and directors were asked to compare the importance of climate risk reporting with the financial reporting they currently receive, a majority of both groups responded that both sets of information are equally important.

\footnotetext{
${ }^{9}$ S\&P Global Report, Best Practices in Corporate Climate Disclosure: How the Leaders Are Lending (2019).
} 
Figure 8: Views of Directors and Investors on Climate Risk Reporting

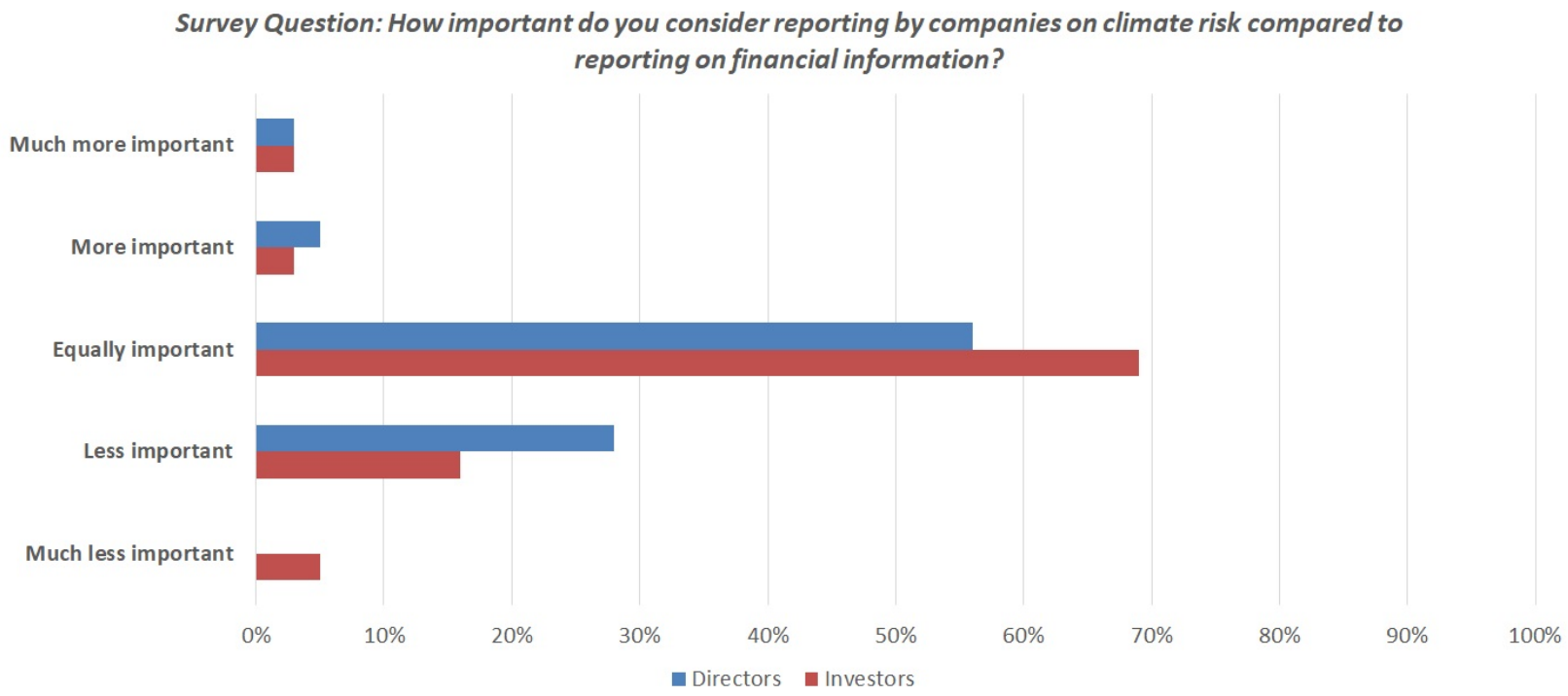

Very few respondents considered climate risk reporting to be more important or much more important than financial reporting, each amounting to less than $10 \%$ of respondents. $30 \%$ of directors answered that climate risk reporting was less important than financial reporting; close to $20 \%$ of investors agreed. On balance, respondents valued climate risk reporting in a meaningful way, even if it may not be the defining element on their current strategy.

That said, investors seemed to find more value in receiving climate-related disclosure than directors. When asked how important they consider reporting by companies on climate risk compared to reporting on financial information, over $70 \%$ of investor respondents found climate disclosure to be equally important in their assessment of investments as a company’s financial information. Only 18\% of investor respondents found climate disclosure to be less important than financial information in their assessment. By contrast, $62 \%$ of director respondents found climate disclosure to be equally important in their assessment as financial information and, ultimately, 30\% of director respondents found climate disclosure to be less important than financial information. Though the gap is not large, investor respondents appeared to find climaterelated disclosure to be more valuable than director respondents. 
Investors also appeared less receptive to boilerplate climate change disclosure language. Instead, investors preferred that companies explain why climate change is material and how it affects their business operations. They believe that companies should quantify the impact of climate change on their business and disclose specific targets they set themselves in order for the climate risk disclosure to be meaningful. Both investors and directors preferred standardized and mandatory climate risk reporting, alongside an integrated report and climate scenario analysis. The propensity of investors and directors to consider climate risk disclosures ultimately depended on the content of the disclosures and its relevance to investment analysis and decision making.

Figure 9: Investors’ Preferences regarding TCFD Recommendations

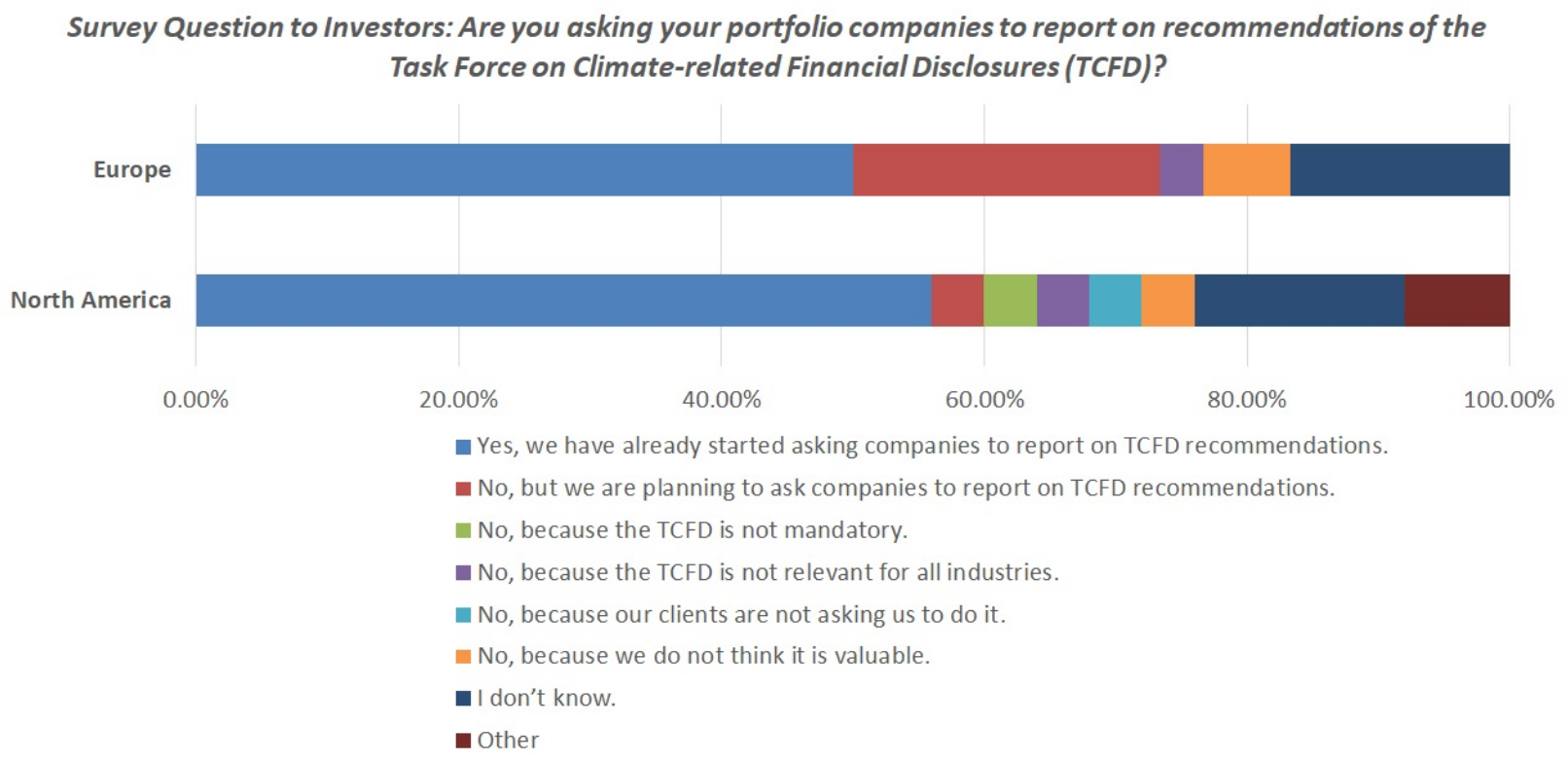

The Task Force on Climate-related Financial Disclosures (TCFD), initiated by the G20 Financial Stability Board, released recommendations for the private sector in response to climate change. The TCFD is tasked with developing a climate disclosure framework companies may use in communications with investors, lenders, insurers, and stakeholders. TCFD 
recommendations work to "improve organizational understanding of the impact of climate risks and reduce the risk of a systemic financial shock on the economy, due to climate change."10 The TCFD recommends that climate disclosures include both transition impacts, which take into consideration risks associated with market changes and macroeconomic factors, and physical impacts, which consider how physical effects of climate change like increased rainfall and sea level rise impact a company's business activities. Most countries have made following the TCFD recommendations voluntary, although France has passed legislation incorporating some elements of the guidelines. ${ }^{11}$ Respondents to this survey were asked whether they, like many other global investors, would prefer disclosures in line with the TCFD recommendations.

Our survey results show that the TCFD reporting recommendations are gaining traction among investors: more than $50 \%$ of investor respondents in both the United States and Europe are already asking companies to follow them. In Europe, $20 \%$ of investor respondents have not yet asked companies to follow the TCFD reporting recommendations but are planning to request such disclosure from portfolio companies. In North America, however, $40 \%$ of investor respondents have not asked portfolio companies to follow TCFD reporting recommendations either because the recommendations are not mandatory, are not relevant to the industries, or because clients have not requested such disclosure. There remains ambiguity in whether investors in both North America and Europe may seek additional avenues to follow TCFD recommendations, as $15 \%$ of respondents indicated that they did not know whether they have asked portfolio companies to provide climate risk disclosure per the TCFD (a figure that may be partially due to the novelty of the framework). ${ }^{12}$ To resolve the ambiguities in these results,

\footnotetext{
${ }^{10}$ EY Global Climate Risk Disclosure Barometer 2020.

${ }^{11}$ EY Global Climate Risk Disclosure Barometer 2018, at page 3.

12 Another reason might be the broad range of roles of investor respondents.
} 
further research could be conducted on how portfolio companies can be incentivized to follow the TCFD reporting recommendations.

The Global Climate Risk Disclosure Barometer 2020 published by EY addressed relevant background factors that relate to our survey results. The report found "all sectors have overall improved their TCFD recommendation disclosures.” However, the report also found that "none of the companies assessed are currently disclosing comprehensive climate risk reporting that would meet the TCFD recommendations.” ${ }^{13}$ Per the report, markets were more responsive to providing quality disclosure where there was "some level of regulation or government support for the TCFD recommendations.” ${ }^{14}$ Our survey results did not differentiate between the level of regulation in each country from which respondents hail and the parts of the financial sector under which the companies are categorized; future research could be more specific to regulatory involvement and the variations between banks, industries, and higher-risk companies.

\section{Views of Directors on Climate Risk Management and Board Oversight}

Climate-related issues were reported to be important topics for boards by their directors. More than $40 \%$ of director respondents indicated that climate-related topics are discussed annually at the board level and 30\% of director respondents replied that they are discussed quarterly by the board. Moreover, nearly 30\% of director respondents believed that boards need to have a non-executive director serving on the board with some level of climate expertise. The fact that almost one-third of director respondents found the need for climate expertise to take on a more pronounced role on the board casts a positive lens on the consideration of ESG issues by director respondents. This is an especially interesting finding as anecdotal evidence suggests that

${ }^{13}$ EY Global Climate Risk Disclosure Barometer 2020.

${ }^{14} I d$. 
many directors actually believe that climate expertise can be achieved at the board level (via trainings, for example) without necessarily having or requiring the election of a non-executive director with specific climate expertise.

Sustainability is becoming a growing concern for directors and constitutes an important (and growing) fraction of ESG issues, according to a March 2018 report from the Deloitte Global Center for Corporate Governance. It plays a role in how a company reviews its operations and strength of the company relative to its competitors. In the past, sustainability typically factored into a company’s assessment of “environmental disasters, labor relations, safety incidents, or scandals," but is now understood to be related to all facets of managing a company. Further research could be conducted on whether directors use enterprise risk management to evaluate sustainability concerns, as suggested in the same March 2018 Deloitte report.

Figure 10: Internal Responsibility for Climate-Related Information

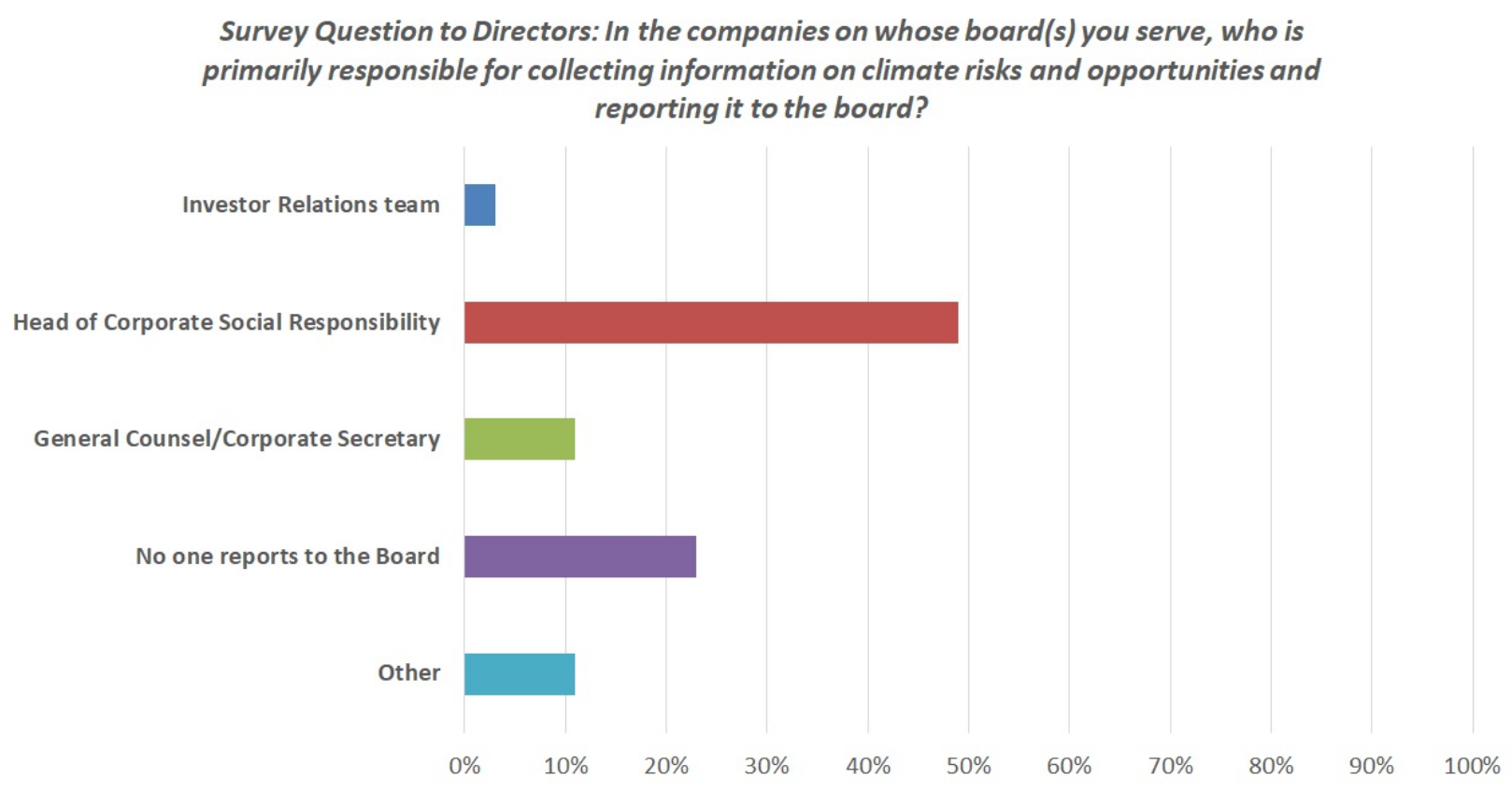


Our survey supports the LeaderXXchange ${ }^{\circledR}$ Investor-Director ESG Working Group’s

prior findings that the board receives climate-related information primarily from the head of CSR/sustainability. ${ }^{15}$ To a lesser extent, the board receives climate-related information from the General Counsel/Corporate Secretary, and almost never from Investor Relations. Approximately a quarter of directors indicated that no one reports to the board on climate-related topics. These findings show that a majority of director respondents have a streamlined method to receive climate-related information on risks and opportunities through reports to the board and utilize those channels.

Figure 11: Engagement with Investors on Climate Change Issues

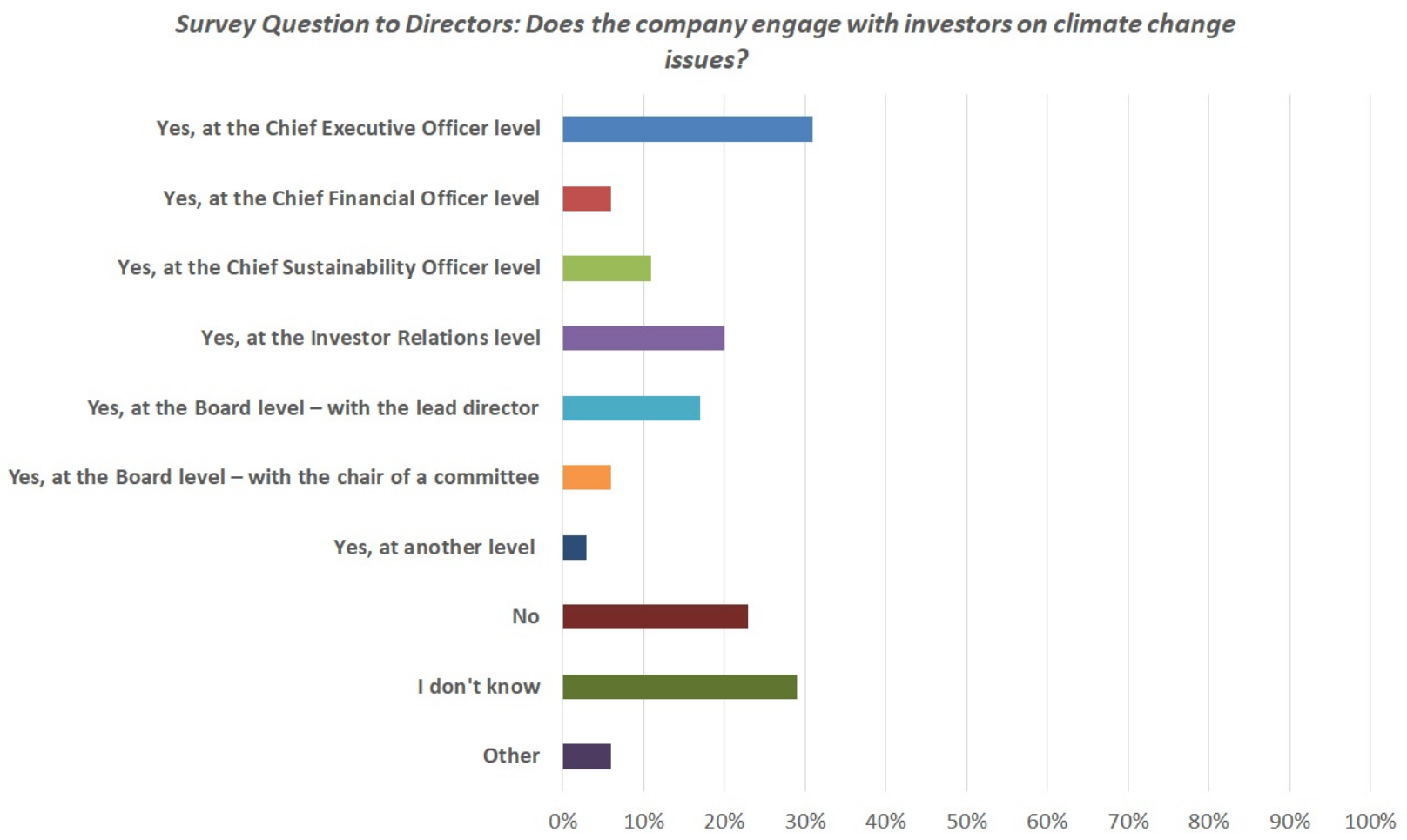

${ }^{15}$ The LeaderXXchange ESG Roadmap was released on January 21, 2020 and draws upon research, discussions, and surveys of LeaderXXchange Investor-Director ESG Working Group members conducted between 2017 and 2019. 
According to director respondents, engagement with investors on climate change issues (when it occurs) takes place primarily at the CEO level and Investor Relations level. This is in line with prior LeaderXXchange ${ }^{\circledR}$ ESG Investor-Director Working Group findings showing that engagement does not take place on the CFO level. More than $20 \%$ of directors indicated that engagement on climate risk also took place at the board level, mainly with the lead independent director. $30 \%$ of director respondents were not aware of whether the company engaged with investors on climate change issues. This finding presents an opportunity to explore how this information gap could be bridged in companies that have not built out communication channels regarding climate risk from the C-suite to investors.

\section{Views of Investors on Stewardship}

To better understand investor communications regarding climate risk, investor respondents were asked, "In your institution, who is responsible for engaging with companies on climate risk?" The survey results suggested a range of investors in different institutional roles are interested in climate change-related issues. Investor respondents said that engagement with companies on climate topics is increasingly done not only by ESG or investor engagement specialists, but also by mainstream portfolio managers and analysts. Even the Chief Investment Officers of asset managers and asset owners (such as pension funds) have begun to engage companies, suggesting the importance of climate topics for the investment industry. 
Figure 12: Responsibility for Climate Change Engagement with Portfolio Companies

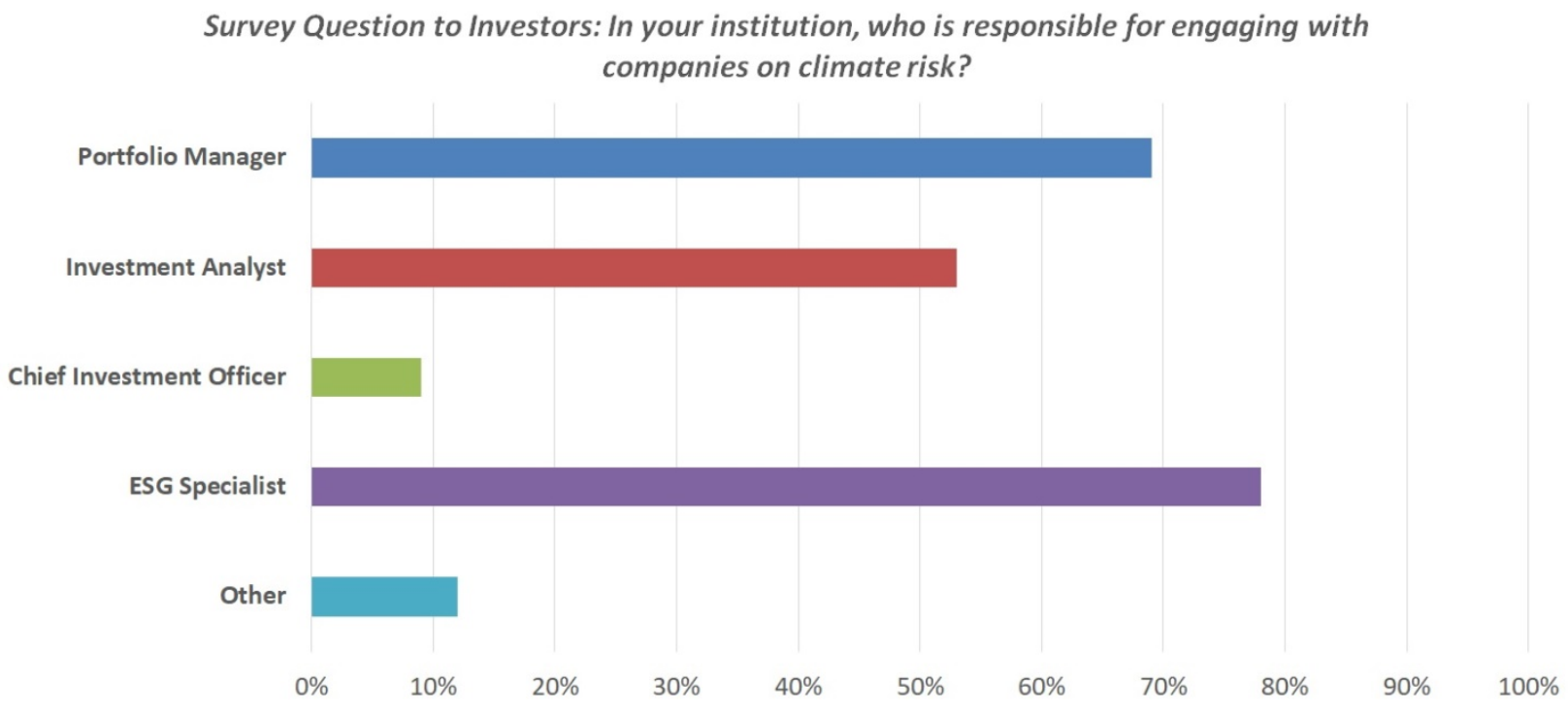

Investor respondents reported that they communicate the importance of climate-risk issues with their portfolio companies in a variety of ways: (i) engaging with management, (ii) submitting or supporting shareholder proposals and/or voting against management, and (iii) engaging board directors in a dialogue. Almost 65\% of investor respondents indicated they engaged directly with board directors. At the intersection of investor and director responses lies a larger question about how their interests align on climate risk and whether there is an opportunity to streamline communications between them on shared concerns regarding climate change. Around $70 \%$ of investor respondents indicated they have submitted or supported shareholder climate proposals and voted against management. 
Figure 13: Forms of Engagement with Portfolio Companies

Survey Question to Investors: How has your institution communicated the importance of climate-risk issues with any of its portfolio companies?

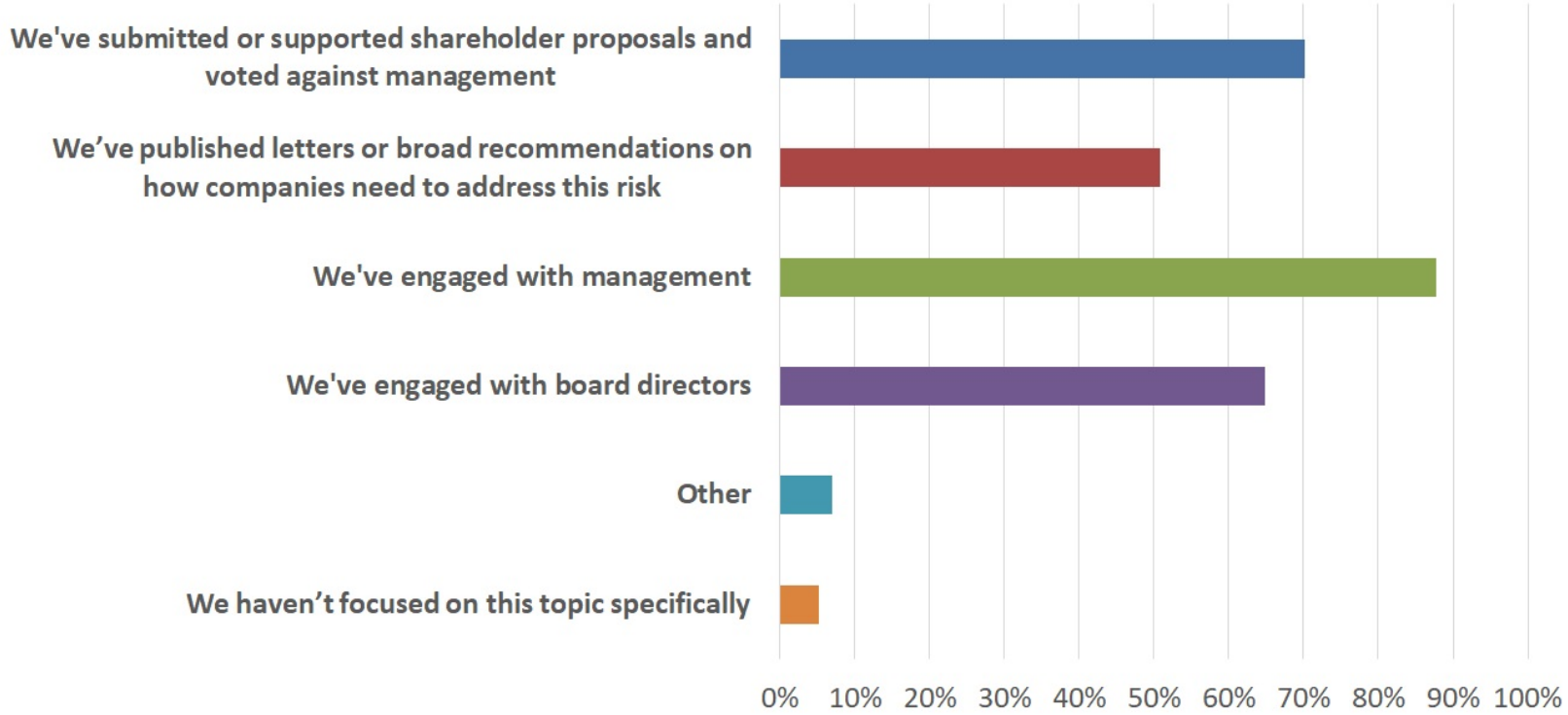

In practice, the picture is not so rosy. While there is encouraging improvement when it comes to voting for climate change resolutions, many investors, especially large U.S. asset managers, still shy away from holding companies accountable, as shown in a 2019 ShareAction report. ${ }^{16}$

\section{Variation by Age and Gender}

Our survey suggests that interest in climate-related issues is correlated to age: the younger the respondent, the greater the interest in climate-related issues. Our survey results support findings of other academic research studies that suggest women are more engaged on climate-related issues than men. However, the gender gap narrows for younger respondents, particularly those under the age of 35 .

\footnotetext{
${ }^{16}$ ShareAction, Voting Matters: Are Asset Managers Using Their Proxy Votes for Climate Action, https://shareaction.org/wp-content/uploads/2019/11/Voting-Matters.pdf (2019).
} 
Our survey shows that the younger the directors, the higher their expectations in terms of corporate disclosure on climate-related issues. Younger directors appear more likely to prefer standardized and mandatory reporting on climate, would like to have climate risks and opportunities incorporated in an integrated report, and believe that companies should conduct a climate scenario analysis. Our survey also found a gender gap on this same issue, with female directors having higher expectations for climate disclosure as compared to their male peers. A study published in the Journal of Corporate Finance recognized that companies with gender diversity on their boards faced fewer environmental lawsuits, indicating that directors who are women may have made strategic decisions to limit corporate environmental litigation risk. ${ }^{17}$ This finding suggests that a diverse range of perspectives on the board can enhance a company's environmental policy, thereby reducing the likelihood of environmental lawsuits. ${ }^{18}$ The implications of this research, taken in conjunction with our survey results, speaks to the need for greater research on the gender gap and the potential that gender diversity may positively affect a company's environmental decision-making.

On the investor side, however, the gender gap appears to be smaller or even nonexistent. One potential explanation for this is that there is a relatively larger proportion of young respondents among male investor respondents. As younger investors tend to be more engaged in climate-related issues (across the board), gender effects seem to abate substantially for this group. These findings are consistent with previous findings of the CFA Institute. ${ }^{19}$ The CFA reported that millennials are most likely to take ESG issues into account in their investment analysis and decisions. Baby boomers, by contrast, can be found on the opposite side of the

\footnotetext{
${ }^{17}$ Research Finds Gender Diverse Boards Are Greener, The University of Adelaide (Aug. 31, 2018), https://www.adelaide.edu.au/news/news102262.html.

${ }^{18} \mathrm{Id}$.

${ }^{19}$ https://www.cfainstitute.org/-/media/documents/survey/esg-survey-report-2017.ashx
} 
spectrum. ${ }^{20}$ Another (not mutually exclusive) explanation is that research broadly suggests there is a gender gap in views on the environment and climate change. ${ }^{21}$ Institutional investors have reported prioritizing gender diversity on boards, so this may be the harbinger of a shifting trend in the coming years. ${ }^{22}$ Generally, investors agreed that gender and/or racial diversity on boards

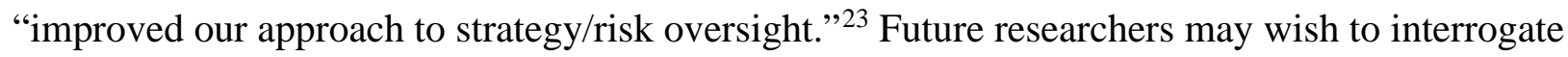
further the relationship between gender diversity and specific types of strategy and risk oversight activities.

\section{Variation by Region}

Our survey suggests that interest in climate-related issues is dependent on region.

Investors in Europe seem to have a higher interest in climate-related issues. When comparing the findings on a regional level, we find that European investors have higher expectations than North American investors in terms of corporate disclosure on climate-related issues. They more strongly prefer standardized and mandatory reporting on climate as well as integrated reports showing both climate risks and opportunities, and they believe that companies should conduct a climate scenario analysis. Our survey does not address whether this is the result of greater regulatory involvement, legislation requiring corporate disclosure on climate-related issues per the TCFD reporting recommendations, or greater investor awareness and action in Europe versus North America, but further research could parse out the influence of regional government on the

\footnotetext{
${ }^{20}$ The same study also found that male investors are more likely than female investors to think that ESG issues are not material.

${ }^{21}$ Matthew Ballew, et al., Gender Differences in Public Understanding of Climate Change, Yale Program on Climate Change Communication (Nov. 20, 2018), https://climatecommunication.yale.edu/publications/genderdifferences-in-public-understanding-of-climate-change/.

${ }^{22}$ For example, in 2018, State Street Global Advisors reportedly voted against directors at 581 companies with allmale boards. PWC, The Evolving Boardroom. Signs of Change (2018). Note that some reports indicate that this trend might have become less important recently. PWC, PwC's 2019 Annual Corporate Directors Survey (2019). ${ }^{23} I d$.
} 
respondents' perspectives. The survey aims to provide a baseline understanding of corporate disclosure in these two regions from which deeper questions might be asked, including whether respondents from countries within Europe or North America have varying expectations on corporate disclosure.

\section{Conclusion}

We close by offering some perspectives on how this set of surveys might be incorporated into the larger public debate around climate change and corporate ownership / governance. By definition, surveys such as this one provide only a single vantage point for understanding and advancing matters of public debate. Accordingly, one should take care not to over-interpret survey results, even in a well-intentioned quest to validate causal intuitions. That said, prudent policy at both the public and private levels can ill afford to commence without being informed by a variety of empirical resources, and this survey represents a promising and important start. We hope to be able to augment this survey in the months and years ahead to consider how investor and director views are evolving, particularly with the onset of the worldwide COVID-19 pandemic (which has spawned a lively debate about whether to accelerate or rein in the reconsideration of stakeholder governance). In addition, the results of this survey may provide intuitions about where and how additional research endeavors might unfold. Our continued attention to this topic is a foregone conclusion, and we hope this contribution will help to propel our evolving knowledge on the topic to the next stage. Delay or hesitation in doing so is a luxury we can ill afford. 


\section{Acknowledgements}

We thank the LeaderXXchange Investor-Director ESG Working Group members for their contributions to the survey. Led by Sophie L'Hélias and Nina Hodzic, the Group was comprised of Investor members Matt Christensen, Natacha Dimitrijevic, Sonia Fasolo, Michael Herskovich, Lee Qian; and Director members Isabelle Azemard, Florence von Erb, Eliane Rouyer-Chevalier, Diane de Saint Victor, and Ulrike Steinhorst.

Copyright (C) 2020 LeaderXXchange LLC. All rights reserved.

Copyright (c) 2020 The Trustees of Columbia University in the City of New York. All rights reserved.

Dissemination of the contents of this report is encouraged. Please give full acknowledgement of the source when reproducing extracts in other published work. All information in this report is provided without warranty of any kind, express or implied. The authors disclaim any responsibility for the information or conclusions in this report. The authors and their organizations accept no liability for any loss arising from any action taken or refrained from being taken as a result of information contained in this report. 